$\xi=-1$

\title{
Reliability of self-employment intentions instrument among international students in Indonesian university
}

\author{
Mhd Subhan ${ }^{1,2}$, Mas'ud Zein ${ }^{2}$, Akhyar², Mohd Hakimie Zainal Abidin', Sallehudin Ali', Salleh Amat', Mohd Izwan \\ Mahmud $^{1}$, Aida Hanim A. Hamid ${ }^{1}$ and Abu Yazid Abu Bakar ${ }^{*}$ \\ ${ }^{1}$ Univerisiti Kebangsaan Malaysia \\ ${ }^{2}$ UIN Suska Riau \\ *Corresponding author E-mail: yazid3338@ukm.edu.my
}

\begin{abstract}
This paper examines the validation instrument used to measure the psychometric status of the self-employment intentions. Selfemployment intentions are crucial to identify the university students in order to confirm their decision making. They are a questionnaire to measure graduation in university to start choice on their careers. This instrument is composed of 11 items and was carried out to 115 international students studying in one Indonesian higher education. There were 49 male and 66 female respondents involved in this study. The Cronbach's Alpha value was .94 which strongly suggest that the instrument has an excellent reliability. This study points out that self-employment intentions are suitable to be used by college personnel and counselors to examine and identify self-employment intentions among international students in Indonesian higher education. Implications for future study will also be discussed.
\end{abstract}

Keywords: Self-Employment Intentions, Psychometric Evaluation, Reliability, Validity

\section{Introduction}

The Career decision making is most of college students' stress and difficulties confronted in a daily basis [1] . The Institutes of Higher Learning in Indonesia are producing an ever-increasing number of graduates every year. Reference BPS [2] reported students graduating from higher education institutes in Indonesia have been increasing firmly over the years to about 787,000 in 2016 . The number of students graduated from bachelor's program takes a big portion comparing to other levels of study. The increased in the numbers of the institute of higher learning may contribute to this scheme. Although it gives the chances to more students to continue their study, according to the graduates' tracer study by Ministry of Higher Education Department, seven percent of students graduated from bachelor's program is still jobless within three to four months after completion of the study. The graduate oversupply contributed to the inequality of many graduates in related to the job vacancies available in the market.

Self-employment is described as the intention to work on oneself [3], the intention to start a business [4] or the intention to own a business [5]. Thrikawala [6] found some young graduates were not in favor to choose entrepreneurship as their career choice. According to Akmaliah [7], the decision to choose an entrepreneur as a career can sometimes depends on personality traits of individuals. Past studies of entrepreneurial intention mostly used Theory of Planned Behavior [8] as theoretical framework.

Theory of Planned Behavior (TPB) emphasizes three kinds of considerations that guide human actions: behavioural beliefs that connects the outcomes and evaluations, normative beliefs that connect motivation and compliance of these motivations and control beliefs that may assist or impede performance and the perceived power [8]. Behavioural beliefs make an individual is in favor or unfavor of particular behavior while normative beliefs create pressure in society or the norms in society. In addition, control beliefs make an individual aware of the anticipated behavioural control. In general, intention is determined by the attitude towards behavior, subjective norm, and perception of behavioural control [9]. The greater the perceived control, the attitude and subjective norm, the greater the individual's intention to perform the behavior [10].

\subsection{Measurement of Self-Employment Intentions}

Most of the measurement to examine self-employment intentions have been expanded and applied in the West [11]. However, those measures are not widely accepted and no one scale was elected as the preferred one [12].

\subsection{This Study}

According to Akmaliah and Hassan [13], self-employment intentions have been well examined in the West but they are less examined in Asian countries. This is to imply that less instruments were used to measure self-employment intentions due to reliability issues. One of the validity issues is the use of the instrument in the non-western population when it is originally developed in the western culture. The purpose of this study is to report the reliability of the Self-Employment Intentions Measure for international students studying in Indonesia.

\section{Methodology}

\subsection{Participants}

This study employs 115 international undergraduate students 
studying in one public university in Indonesia. The selected participants were informed about the purpose of the study in evaluating the self-employment intention [14]. Among 115 participants, 49 $(43 \%)$ were male and $66(57 \%)$ were female. The mean age of the involved participants is 22.4 years old. Purposive sampling procedure [15] was utilized in this study where the researchers gather the participation of international students at the International of fice, library, and international student residence.

\subsection{Instruments}

The instrument was developed based on the modification of previous instruments which are developed by several authors such as Ajzen and Fishbein [16], Kolvereid [17], Krueger [18], Chen, Green and Crick [19], Hassan [20] and Akmaliah and Hassan [13]. The instrument of self-employment intentions were applied in this study. The self-employment intentions are composed of eleven items; all positive items. According to Hassan and Akmaliah [13], items 1-11 are stated positively. Respondents were asked to answer each item by using the following 5 point Likert Scales with 1 demonstrating "strongly disagree" to 5 demonstrating "strongly agree". The items which were written negatively are regraded so that higher scores resonated its mean. Akmaliah and Hassan [13] also affirmed the reliability and validity of the instrument. The instrument showed the value of Cronbach's alpha ranging from .65-.96. Convergent validity and discriminant predictive validity were also explored by Akmaliah and Hassan [13] as part of the validation analysis.

\subsection{Data Analysis}

The data were analyzed using SPSS 22.0. The primary analysis is to examine: first, the reliability, secondly, factor structure, and finally, the validity of the instrument. The factor structure was investigated by principal component analysis (PCA) and the internal consistency was measured by using Cronbach's Alpha.

\section{Results and discussion}

At the beginning stage, we determined mean and standard deviation of the self-employment intentions. Analysis resulted the mean value of self-employment intentions is 2.69 and the standard deviation of the scale is 7.95 . There were significant inter-item correlations discovered in the self-employment intentions. The analysis showed that the values of inter-item correlation are between .33 and .96 (Table 1). All values are found positive, indicating that the items shared similar characteristics or constructs. According to Field $^{21}$, a correlation value between .30 and .90 is agreeable to implement deeper analysis. The data demonstrated that there are no multicollinearity issues.

Based on Table 1, Principal Component Analysis (PCA) was carried out
As shown in Table 2, the Bartlett Sphericity Test is strongly significant, $\chi 2$ $(55)=1243.534, p=.000$, therefore factor analysis is appropriate. The Kaiser Mayer Olkin that measure a sample of adequacy $(\mathrm{MSA}=.864)$ was bigger than the minimally agreed level of .5. This result shows that the study has completed the sampling adequacy requirement for factor analysis $[21,22,23]$. According to Bartlett test of Sphericity and the Kaiser Mayer Olkin, it can be achieved that Self-Employment Intentions met the precondition for the application of PCA.

The validity of the Self-Employment Intentions was tested by using PCA [24]. Factor analysis method was used to access the construct validity of the instrument. Principle component analysis (PCA) decides the factors accounting for the total variance of the specific construct. The factor analysis indicates that there was a single factor of eigenvalues above 1.0 This carries $65.37 \%$ of the total variance (Table 3). The values of factor range from .60 to .90 (Table 4). All eleven items were found agreeably well in a single factor. In general, a factor value of .40 is accepted in factor analysis which suggests that the items can be involved in the scale [22,25]. The coherent characteristics of a scale can be examined by its internal consistency. Streiner proposed, "One of the central tenets of classical test theory is that scales should have a high degree of internal consistency, as evidenced by Cronbach's Alpha" (p. 217). Meanwhile, the Cronbach's Alpha value was .94 showing that the scale has excellent reliability [22]. No item was erased as the value of the coefficient alpha is relevant. Table 5 shows the value of Cronbach Alpha if items were removed.

\section{Conclusion}

To summarize this study, the self-employment intentions established by Ajzen and Fishbein [16], Kolvereid [17], Krueger [18], Chen, Green and Crick [19], Hassan [20], and Akmaliah and Hassan [13] is considered as a reliable and valid scale for the measurement of self-employment intentions among international students in Indonesian university. Principle component analysis produced a single component of self-employment intentions which is suitable with the single factor of self-employment intentions expanded by Ajzen and Fishbein [16], Kolvereid [17], Krueger [18], Chen, Green and Crick [19], Hassan [20] and Akmaliah and Hassan [13]. The reliability of the scale was high because the value of Cronbach alpha was .94 .

Despite its high value of psychometrics properties, further validation studies are needed to support this findings, in a wider population. Additionally, this self-employment intention could be developed by correlating this instrument with other instruments that measure self-employment or entrepreneurship career. The findings of this study are restricted with convenience sampling of international students in a public university in Indonesia. Future study suggests that a larger population involving several other universities in Indonesia should be examined.

In summary, this Self-Employment Intentions is highly recommended for college personnel and counselors to examine the decision making choice career self-employment intentions among university students. The questions are user-friendly because the items are easily understood and it does not take long to complete the instrument. The university counselors could use this instrument to gain initial information about career choices made by the students. Hence, suitable support and counseling services could be designed to cater the needs of these students.

Table 1: The Self Employment Intentions

\begin{tabular}{|c|c|c|c|c|c|c|c|c|c|c|c|c|}
\hline \multicolumn{13}{|c|}{ Correlation Matrix } \\
\hline & & Item 1 & Item 2 & Item 3 & Item 4 & Item 5 & Item 6 & Item 7 & Item 8 & Item 9 & Item 10 & Item 11 \\
\hline \multirow{11}{*}{ Correlation } & Item 1 & 1.000 & .469 & .460 & .442 & .453 & .480 & .427 & .457 & .329 & .464 & .487 \\
\hline & Item 2 & .469 & 1.000 & .535 & .712 & .526 & .642 & .739 & .589 & 615 & .611 & .631 \\
\hline & Item 3 & .460 & .535 & 1.000 & .708 & .367 & .682 & 680 & .967 & 647 & .661 & .624 \\
\hline & Item 4 & .442 & .712 & .708 & 1.000 & .563 & .773 & .758 & .742 & .818 & .671 & .683 \\
\hline & Item 5 & .453 & .526 & .367 & .563 & 1.000 & .505 & .551 & .461 & .433 & .532 & .431 \\
\hline & Item 6 & .480 & .642 & .682 & .773 & .505 & 1.000 & 677 & .706 & .693 & .695 & .841 \\
\hline & Item 7 & .427 & .739 & .680 & .758 & .551 & .677 & 1.000 & .692 & .693 & .664 & .638 \\
\hline & Item 8 & .457 & .589 & .967 & .742 & .461 & .706 & .692 & 1.000 & .658 & .699 & .611 \\
\hline & Item 9 & .329 & .615 & .647 & .818 & .433 & .693 & .693 & .658 & 1.000 & .593 & .744 \\
\hline & Item 10 & .464 & .611 & .661 & .671 & .532 & .695 & .664 & 699 & .593 & 1.000 & .664 \\
\hline & Item 11 & .487 & .631 & .624 & .683 & .431 & .841 & .638 & .611 & .744 & .664 & 1.000 \\
\hline
\end{tabular}


Table 2: KMO and Bartlett's test

\begin{tabular}{lcc}
\hline Kaiser-Meyer-Olkin Measure of Sampling Adequacy & 0.864 \\
\hline Bartlett's Test of Sphericity Approx. Chi-Square & 1243.534 \\
df & 55 \\
Significant & 0.000 \\
\hline
\end{tabular}

Table 3: Total variation that can be determined

\begin{tabular}{|c|c|c|c|c|c|c|}
\hline \multicolumn{7}{|c|}{ Total Variance Explained } \\
\hline \multirow{2}{*}{ Component } & \multicolumn{3}{|c|}{ Initial Eigenvalues } & \multicolumn{3}{|c|}{ Extraction Sums of Squared Loadings } \\
\hline & Total & $\%$ of Variance & Cumulative \% & Total & $\%$ of Variance & Cumulative $\%$ \\
\hline 1 & 7.190 & 65.368 & 65.368 & 7.190 & 65.368 & 65.368 \\
\hline 2 & .860 & 7.814 & 73.182 & & & \\
\hline 3 & .707 & 6.426 & 79.608 & & & \\
\hline 4 & .588 & 5.350 & 84.957 & & & \\
\hline 5 & .448 & 4.070 & 89.027 & & & \\
\hline 6 & .387 & 3.515 & 92.542 & & & \\
\hline 7 & .275 & 2.502 & 95.044 & & & \\
\hline 8 & .234 & 2.123 & 97.167 & & & \\
\hline 9 & .197 & 1.793 & 98.960 & & & \\
\hline 10 & .092 & .835 & 99.795 & & & \\
\hline 11 & .023 & .205 & 100.000 & & & \\
\hline
\end{tabular}

Table 4: Component matrix

\section{Component Matrix ${ }^{\mathrm{a}}$}

1. I will choose a career as an entrepreneur

2. I prefer to be an entrepreneur rather than be an employee in a company

3. I am prepared to do anything to be an entrepreneur

4. I'll make every effort to start and run my own business

5. I have thought seriously to start my own business after completing Study

6. I have a strong intention to start a business someday

7. I'm determined to create a firm in the future

8. I put effort to make more money

9. I want to be my own boss

10. I will start my business in next 5 years

11. I will start my business in next 10 years

Component Item

.595

.797

.836

.895

.640

.874

.853

.863

.825

.820

.835

Extraction Method: Principal Component Analysis.

Table 5: The Self-employment Intentions: Cronbach's Alpha if item deleted

\begin{tabular}{|c|c|c|c|c|}
\hline \multicolumn{5}{|l|}{ Item-Total Statistics } \\
\hline & $\begin{array}{c}\text { Scale Mean if Item } \\
\text { Deleted }\end{array}$ & Scale Variance if Item Deleted & $\begin{array}{c}\text { Corrected Item-Total Correla- } \\
\text { tion }\end{array}$ & $\begin{array}{c}\text { Cronbach's Alpha if Item De- } \\
\text { leted }\end{array}$ \\
\hline Question 1 & 28.36 & 59.725 & .541 & .946 \\
\hline Question 2 & 26.75 & 53.769 & .752 & .938 \\
\hline Question 3 & 26.61 & 52.188 & .786 & .936 \\
\hline Question 4 & 26.62 & 49.975 & .869 & .932 \\
\hline Question 5 & 27.84 & 52.537 & .577 & .947 \\
\hline Question 6 & 26.56 & 50.897 & .839 & .934 \\
\hline Question 7 & 26.64 & 51.723 & .818 & .935 \\
\hline Question 8 & 26.54 & 51.338 & .822 & .934 \\
\hline Question 9 & 26.51 & 51.270 & .784 & .936 \\
\hline Question 10 & 26.62 & 53.271 & .778 & .937 \\
\hline Question 11 & 26.57 & 51.580 & .788 & .936 \\
\hline
\end{tabular}

\section{References}

1] Ali IA (2014), Factors Influencing Self-Employment Intention among Nigerian Post-Graduate Students of Universiti Utara Malaysia (UUM). Thesis submitted to Othman Yeop Abdullah Graduate School of Business Universiti Utara Malaysia.

[2] Badan Pusat Statistik (2016): "Keadaan Ketenagakerjaan 2016". Berita Resmi Statistik. No. 33/05/Th. XV, 7 Mei 2016. (The state of employment 2016. Official statistics published by Statistics Indonesia.)

[3] Douglas EJ \& Shepherd DA (2002), 'Self-Employment as a Career Choice: Attitudes, Entrepreneurial Intentions, and Utility Maximization', Entrepreneurial Theory and Practice 26(3), 8190.
[4] Zhao H \& Seibert SE (2006) 'The Big Five Personality Dimensions and Entrepreneurial Status: A Meta-Analytical Review', Journal of Applied Psychology 91(2), 259-271.

[5] Crant JM (1996), 'The Proactive Personality Scale as a Predictor for Entrepreneurial Intention', Journal of Small Business Management 34(3)

[6] Thrikawala S (2011), The Determinants of Entrepreneurial Intention among Academics in Sri Lanka. Singapore: LACSIT Press.

[7] Akmaliah Z (2009), 'Entrepreneurship as a Career Choice: An Analysis of Entrepreneurial Self-Efficacy and Intentions of University Students', European Journal of Social Research 9(2): 338349.

[8] Fishbein M \& Ajzen I (2010), Predicting and Changing Behavior: The Reasoned Action Approach. New York: Taylor \& Francis.

[9] McEachan RRC, Conner M, Taylor NJ \& Lawton RJ (2011), 'Prospective Prediction of Health-Related Behaviours with the Theory 
of Planned Behaviour: A Meta-Analysis', Health Psychology Review 5(2), 97-144.

[10] Herzog NV (2010), 'Business Process Reengineering and Measuring of Company Operations Efficiency', in A. Gunasekaran, \& M. Sandhu (eds.), Handbook on Business Information System, pp. 117-146. Singapore: World Scientific Publishing Co.

[11] Van Der ZP (2013), Entrepreneurship Education and SelfEmployment: The Role of Perceived Barriers, 1-25.

[12] Rantanen T \& Toikko T (2013), 'Social Values, Societal Entrepreneurship Attitude and Entrepreneurship Intention of Young People in the Finnish Welfare State', Poznan University of Economics Review, 13(1).

[13] Akmaliah Z \& Hassan H (2009), 'Choice of Self-Employment Intentions among Secondary School Students', The Journal of International Social Research 2(9): 539- 549.

[14] Moumita, S., \& Tapash, R.S. (2014). 'Assessment of SelfEmployment Intention through Analyzing Entrepreneurial Characteristics: A Study on MBA Students in Kolkata', AIMA Journal of Management \& Research, 8(3/4).

[15] Sekaran U \& Bougie R (2013),. Research Methods for Business: A Skill Building Approach. Chichester, UK: Willey.

[16] Ajzen I \& Fishbein M (1980), Implementing Attitudes and Predicting Social Behavior. Englewoods Cliffs, CA: Prentice Hall.

[17] Kolvereid L (1996), 'Organisational Employment versus SelfEmployment: Reasons for Career Choice Intentions', Entrepreneurship Theory and Practice 20(3), 23-31.

[18] Krueger NF, Reilly MD \& Carsud AL (2000), 'Competing Models of Entrepreneurial Intention', Journal of Business Venturing, 15, 411-432.

[19] Chen CR \& Crick A (1998), 'The Self-Efficacy Expectations and Occupational Preferences of Females and Males', Journal of Business Venturing 13(4), 295-316.

[20] Hassan H (2007), Hubungan faktor terpilih dengan tekad keusahawanan mengikut persepsi pelajar. Unpublish Master Thesis, Universiti Putra Malaysia.

[21] Field A (2009), Discovering Statistics using SPSS. Beverly Hills, CA: Sage.

[22] Hair JE, Anderson RE, Tantham RL \& Black WC (1998), Multivariate Data Analysis. Upper Saddle River, NJ: Prentice-Hall.

[23] Kaiser HF (1974), 'An Index of Factorial Simplicity', Psychometrika 39, 31-36.

[24] Grove SK, Burns N \& Gray JR (2013), The Practice of Nursing Research; Appraisal, Synthesis, and Generation of Evidence. St. Louis, MI: Elsevier.

[25] Nunnally JC \& Bernstein IH (1994), Psychometric theory. New York: McGraw-Hill. 